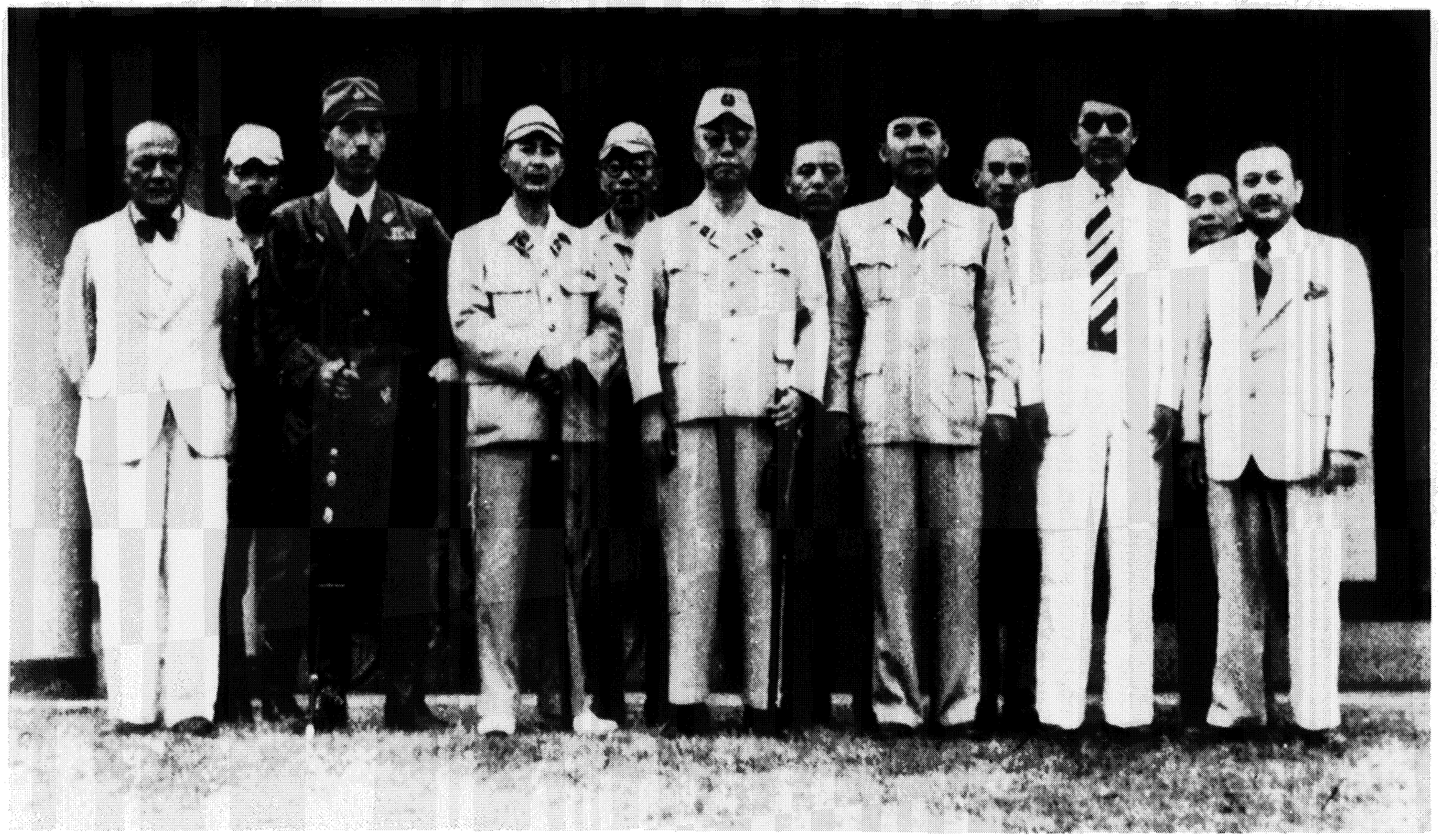

At the time of Sukarno's visit to Makassar on April 30, 1945, the day after the Emperor's birthday, an announcement was made that the nationalists' anthem and the flying of their flag had received official Japanese approval. Taken outside the residence of the Naval Governor (front row, left to right): Dr. G. S. Ratulangie, from Manado; Admiral Maeda; Ichiki, in charge of Naval Civil Administration; Mitsuhashi, Naval Area Governor; Sukarno; Tadjuddin Noor; A. Subardjo; (back row) Hayashi Kenichi, who coordinated espionage in prewar Indies and Navy propaganda during the war, and after the war became a novelist; Captain Yanagihara Masuzo, Chief of Political Bureau; Nishijima; Sumanang; Yoshizumi. Photo supplied by Nishijima at time of interview. 


\title{
THE LOVEDAY EXCHANGE, Australia, 1942 : THE JAPANESE NAVAL SPIES RETURN TO JAVA
}

\author{
Greg Poulgrain
}

When Nishijima Shigetada visited Jakarta in 1991, he was greeted as an historical hero. His first arrival there in 1937 had been under the auspices of Japanese Naval Intelligence. With a background in Tokyo of university studies in German language and an early interest in international affairs, particularly the war in China, Nishijima had been recruited by Naval Intelligence to increase Japanese influence in the Nanyang, the region of the Southern Seas. Six months before his arrival in July of 1937, parliamentary debate in Japan had focused on possible Japanese colonization of Netherlands New Guinea. This unexplored territory covered half of the world's largest tropical island-so large that it equaled the combined area of the four main islands of Japan. Advancing Japanese aspirations in the Nanyang, in commerce or in discussions regarding colonization, caused the Dutch government in Batavia to upgrade its surveillance of all who promoted Indonesian nationalism among the colonial subjects. Nishijima, however, escaped detection, despite the fact that his prewar tasks involved fostering the spirit of independence and "collecting information regarding Indonesia, that is, the Netherlands East Indies." 1

On his arrival in Java, Nishijima worked first in a chain of department stores in Surabaya, Batavia, and Bandung. He and other Japanese who were similarly undercover established links with Indonesian nationalists. "It was very difficult for us to have contact with those people. The Dutch were very strong and severe. There was no chance at all to have direct contact with these people. However, we found a clandestine channel." 2 At the same time, Nishijima became fluent in Dutch and Indonesian.

Dutch security forces arrested Nishijima and 1,700 other Japanese living in the Netherlands East Indies at the start of the war in the Pacific, ${ }^{3}$ and transported them in two shiploads to Australia for internment. Among the detainees was Yoshizumi Tomegoro, a close friend of Nishijima, and editor of the prewar Japanese newspaper in Batavia, Tohindo

1 Interview by G. Poulgrain of Nishijima Shigetada in his home in Tokyo, August 13-20, 1983. Hereafter referred to as Nishijima Interview.

2 Nishijima Interview.

3 Acting upon a Japanese government recommendation, Nishijima's wife and two sons (and many others not directly involved in "collecting information") returned to Japan in September 1941. Nishijima Interview. 
Nippon. Dutch Security had earlier intercepted letters from Yoshizumi in which he advocated a "campaign for the new order in East Asia," and "Asia for the Asiatics." As a result he had been deported but had returned secretly to the Indies on a fishing vessel, and was arrested again on December 8, 1941 "disguised in native dress and with fl.57,000 [Dutch guilders] in his possession-ready money which he admitted having received from the Consulate General."4 Yoshizumi was listed as one of the "Naval spies," and this was confirmed by Nishijima who explained that Yoshizumi held "a special position in the Japanese Navy," whereas he himself was not a career-member of the Navy, but rather "a civilian attached to the Navy and promoted to an officer." 5

When the war began, both Nishijima and Yoshizumi were thirty years of age. They were shipped from the Indies at the end of January 1942 on the Cremer, and the Heemskerk carried a second shipload of detainees to Australia. The 1,700 Japanese from the Netherlands East Indies were interned at Loveday Camp in South Australia. Loveday, then 230 miles from Adelaide on the Melbourne rail-link, had been a hamlet of three houses and an old airstrip before the camp's construction. Designed to house 5,000 male internees of Italian, German, and Japanese nationalities, Loveday Camp was under command of Lieutenant Colonel Dean, assisted by more than a thousand officers and men. Internees were defined by Dean as those "whose activities might be detrimental to the successful prosecution of the war effort." 6

Dutch Security had meticulously documented the activities of many Japanese in the Indies in a White Paper entitled Ten Years Japanese Toil In The Netherlands East Indies. ${ }^{7}$ This intelligence report covering Japanese fifth column activity in the Netherlands East Indies was sent to Australia one month before the Indies surrendered to Japan on March 8, 1942. It included many details clearly identifying some Japanese internees as politically subversive, and some as "Naval spies." In addition to Yoshizumi, for example, there were two other journalists linked with Japanese Intelligence, Ichiki Tatsuo and Kubo Tatsuji. Kubo had been in the Indies for thirty years. In 1934 in Batavia, he founded a newspaper, Nichiran Shogyo Shinbun or The Japanese-Dutch Commercial Times. ${ }^{8}$ Letters intercepted by the Dutch between Kubo and another Japanese, whom Dutch Security described as a Naval spy, Kaneko Keizo, showed that the two were financing subversive activities. ${ }^{9}$ (Kubo died in a plane crash a year after his release from Loveday; ${ }^{10}$ Ichiki $^{11}$ and Yoshizumi ${ }^{12}$ both died during the Indonesian war of independence.)

\footnotetext{
4 A full report on Yoshizumi's activities is in the Dutch report, Ten Years Japanese Toil in the Netherlands East Indies, Official Report of the Indies Government compiled by the Office of East Asiatic Affairs under A.H.J. Lovink, Batavia, 1942. Located at the Australian Archives, Brighton, Melbourne. MP 729/6 Box 57 22/401/381. This intelligence report is in Dutch and English with copies of original Japanese documents also translated into both languages.

${ }^{5}$ Nishijima Interview.

${ }^{6}$ Lt. Colonel E. T. Dean, DSO, Internment in South Australia, National Archives, Canberra, CRS A2663 780/7/1.

7 See above, note 4 .

8 In July 1937, this newspaper changed its name to Tohindo Nippon. See Kenichi Goto, "Life and Death of 'Abdul Rachman' (1906-49): One Aspect of Japanese-Indonesian Relationships." Indonesia 22 (October 1976): 65.

${ }^{9}$ See Ten Years' Toil, pp. 97-111.

${ }^{10}$ Nishijima Interview. To confirm this during the interview, Nishijima telephoned his former chief from the prewar days in Java, Taro Ishi, who was then 96 years of age. Taro Ishi was in the Loveday exchange but, Nishijima explained, he was "a real civilian."

11 Kenichi Goto, "Life and Death of 'Abdul Rachman," p. 57.

12 Nishijima Interview.
} 
The Japanese advance on the Indies began on January 11, 1942 with parachutists occupying the major oil sites at Tarakan and Balikpapan in Borneo. In Netherlands New Guinea, evacuation was possible for only a few non-Indonesian inhabitants. ${ }^{13}$ While this chaos was continuing in mid-February, the Consul-General for the Netherlands in Australia sent the Eastern Command in Sydney a copy of the White Paper on Japanese subversive activities in the Indies. On February 18, it was sent from Sydney to Canberra, still in the Dutch language, but two days later the Security Intelligence Center in Canberra had still not received the copy and their desperation was evident. They had not yet seen it, they explained, "let alone an English version", and urgently requested the report "as there may be some material of vital use therein."14 Australian Military Intelligence would presumably have been one of the first agencies to receive and assess this document but scrawled across a letter from Eastern Command to Canberra was their reply: "No copy received in M.I." Thus the likelihood of linking the names of the Loveday internees before their repatriation with those in the White Paper became negligible.

In August 1942, Nishijima was one of 834 Japanese included in a Repatriation Exchange from Australia to Java. This exchange took place despite the information the Allies had obtained from the detailed Dutch intelligence White Paper, which included names and photographs of some Japanese described as "Naval spies," who had been active up to December 1941 before being sent to Australia. ${ }^{15}$ Nishijima's political activities in prewar Java had not been detected by Dutch Security, and so his name was not included in the report. His return to Java and presence there during the period of the Japanese occupation may thus be regarded as an accident of war. ${ }^{16}$ This is also the case with other Japanese political experts participating in the exchange, whose camaraderie with Indonesian nationalists sprang from prewar friendships, and who also became an integral part of the Indonesian independence struggle. However, there is no explanation for the inclusion in the exchange of other Japanese whose prewar activities had been detected by Dutch Security. Letters intercepted by the Dutch showed the scale of some anti-Dutch activities and linked prominent Japanese businessmen in Batavia to the Japanese Navy. ${ }^{17}$ It should be stressed that the initial rationale underlying the Dutch decision to intern the Japanese in Australia was based on accurate political prognosis. The Japanese experts were indeed a formidable force determined to

${ }^{13}$ In Netherlands New Guinea, 90 percent of the remaining Dutch population (amounting to several hundred persons) were killed, according to Peter Schumacher, a former internee in wartime Java who later became a newspaper editor in Amsterdam. Interviewed by G. Poulgrain, September 15, 1984, Amsterdam.

14 "Let alone an English version" might suggest that the White Paper had been directed to a translator, but no records to this effect were located, nor any on the whereabouts of the White Paper in the succeeding months. As of September 1941, the American military attaché in Canberra was Colonel Van Santvoord Merle-Smith, but there was no evidence his assistance in translation was sought.

${ }^{15}$ Ten Years Japanese Toil.

16 In 1951, Nishijima compiled a memoir Dai-san no Shinso [The Third Truth] that was not published. In it he acknowledged that he was interned in Australia in early 1942 and was returned to Java later that year. See Nishijima Shigetada, "The Nationalists in Java, 1943-1945" in The Japanese Experience in Indonesia: Selected Memoirs of 1942-1945, ed. Anthony Reid and Oki Akira. Monograph No. 72, (Athens, Ohio: Ohio University Center for Southeast Asian Studies, 1986), p. 263.

${ }^{17}$ For instance, in Netherlands New Guinea in 1935, the Dutch policy of keeping out American oil exploration was suddenly reversed when Dutch Security intercepted plans by the Japanese to commence secret oil exploration. Dutch colonial settlements in the vast territory were established in only ten, small, coastal sites and the proposed Japanese oil exploration made a mockery of the Dutch claim to sovereignty. Even when Royal Dutch Shell joined with American oil companies, Royal Dutch Shell retained only a 40 percent interest in New Guinea exploration -and oil was discovered immediately! See Ten Years Japanese Toil, p. 115. The names of the Japanese involved were Mizuno Tsunemichi, Saito Bunya, and Kosugi Michinari. 
undermine Dutch colonial control. (The Japanese who were not repatriated spent the entire war in confinement, or rather, growing vegetables, pyrethrum for insecticide, or opium poppies for the wartime production of morphine, at the Loveday internment camp.)

Was the failure to exclude the "Naval spies" from the repatriation exchange an administrative blunder? An earlier repatriation involving German nationals interned in the Netherlands East Indies prompted the Australian government to voice concern that some internees, if released, might assist the German war effort through their strategic regional knowledge. ${ }^{18}$ Enthusiasm to deny prewar Japanese visitors the opportunity of acquiring local intelligence had been clearly evident on occasions such as in October 1941, when a Major Haishida (accompanied by Vice-Consul Otabe from Sydney) traveled to Adelaide, and before their arrival the Mount Lofty tourist telescope was hastily dismantled. Australian authorities, it would seem, were not oblivious to the possibility that the Japanese internees included in the repatriation exchange in 1942 had strategic value, yet the ultimate irony of the Loveday exchange was that it was neither initiated nor organized from within Australia.

An interesting question is whether the inclusion in the exchange of Japanese known to be "Indonesian experts" was a deliberate stratagem to hinder the return of a postwar Dutch colonial government? If this were the case and their likely influence in Java was known, it can be speculated that the Allied overseers of the exchange considered the return of their own, predominantly British, personnel to be of greater importance than the loss of these Japanese. Tokyo itself did refuse to include some Allied personnel, named specifically, who were said to be linked with Allied Intelligence. ${ }^{19}$

In his early research on the Japanese in Indonesia Harry J.Benda passed, apparently unsuspectingly, over the six-month hiatus in the service of some Japanese in occupied Java. According to Benda:

Over one thousand Japanese residents had lived on Java for many years, and doubtless they had been assigned key roles in the Japanese military administration. The Dutch, by removing them to Australia after the outbreak of the Pacific War, had deprived the invaders of these local 'experts', while another group of civilians destined for administrative functions on Java was lost in the Battle of the Java Sea. It is not too astonishing, then, that Japanese occupation policy moved slowly, since only gradually could some Japanese with local experience be assigned to important positions. ${ }^{20}$

\footnotetext{
$18 \mathrm{Six}$ months before war in the Pacific, there was an exchange of Dutch businessmen and German internees held in camps in the Netherlands East Indies. Concern was expressed by the Australian Prime Minister (telegram 317, May 25, 1941) that "discrimination would be exercised in the release of men who might be dangerous by reason of their special knowledge of local conditions and geography." Also, Lt. Colonel Chapman of Australian Military Intelligence, drew attention (Defence memoranda 19/305/70, May 13 and 18, 1940, from the Australian Government Commission in Batavia) to some 4,000 internees, Germans and Dutch National Socialists (NSB). "Owing to the news of the invasion of Holland not reaching the Nazi leaders in the N.E.I. promptly or before it took place, they were caught and so [Dutch Security] prevented any coup."

19 Japanese authorities refused to include two Australians, Bowden and Ross, from Singapore and Timor respectively.

20 Harry J. Benda, "The Beginnings of the Japanese Occupation in Java," in Continuity and Change in Southeast Asia - Collected Articles of Harry J. Benda, Monograph Series No. 18 (New Haven: Yale University Southeast Asia Studies, 1972), p. 65.

See also: G. S. Kanahele, "The Japanese Occupation of Indonesia: Prelude to Independence," (PhD thesis, Cornell University, 1967), p. 59 and p. 278. Kanahele explained that "a few [Japanese] had been repatriated via Australia immediately after the war began," but he did not consider their repatriation significant.
} 
One such expert (not named in Benda's article) was "the former editor of Tohindo Nippon."21 According to Benda, the former editor was appointed in late 1942 to study the constitution of Java. As in the case of Nishijima, the assumption was that this editor had avoided being detained by the Dutch in December 1941 and had somehow resurfaced in late 1942. This editor was, of course, Nishijima's friend Yoshizumi Tomegoro, who had been interned in Australia and returned under the Loveday exchange. In the repatriation documents relating to Yoshizumi, internment number IJ 50714, his occupation was stated simply as "nil," indicating the intelligence report was still not available when officials at Loveday compiled identification reports on the Japanese internees. The disappearance of the document amounted to a serious discontinuity in wartime intelligence which (if deliberate) was in contravention of the US War Department proposal for a full exchange of military intelligence in the Far East. Six months remained for the breakdown to be rectified, but it was not. The White Paper did surface later in the United States and was published in February 1944, under the title "Ten Years Japanese Burrowing in the Netherlands East Indies." How this happened has not been ascertained. Research on this subject among the archival materials has suffered from a lack of complete records, but there is evidence to indicate that Washington authorized the Repatriation Exchange.

In an eleventh-hour stand against the Japanese invasion, an American-British-DutchAustralian command (ABDACOM) was formed under General Sir Archibald Wavell, but only a month after he arrived in Batavia on January 10, 1942, to establish command headquarters, ABDACOM was dissolved. There was great confusion in setting up an American command in Australia. At first the command was under Wavell's deputy, an American, Major General Brett, and there were five changes of command by April 14, 1942, when General MacArthur was appointed Supreme Commander. MacArthur assumed command of all South West Pacific Area forces four days later, and he set up his headquarters in Melbourne. In July he moved north to Brisbane, thus employing the tactic which later became synonymous with his advance: by hopping over Sydney, he bypassed General Blamey in the Australian Eastern Command. Rivalry between the two had developed over troop displacement and policy in New Guinea.

Australian Prime Minister Curtin was known to be openly seeking General MacArthur's opinion on the repatriation, a political gesture that Blamey was loath to make. On May 26, 1942, Curtin had shown MacArthur a cable concerning the proposed repatriation exchange, and MacArthur's advice was recorded in handwriting on the text of the cable. The penciled notation stated: "Com. S.W. Pacific says this is entirely a matter for Washington."

The first proposal for an exchange came through Switzerland and was intended to include all members of embassies, legations, and consulates. Any non-officials included were to be non-permanent residents. Three weeks after the Japanese internees arrived at Loveday, a suggestion came from the United States that Lourenco Marques (now Maputo on the southeast coast of Africa) should be the locality for the exchange. The Japanese from the Indies seemed to fit satisfactorily into the category of "non-permanent residents," even though it had been intended for the likes of visiting seamen.

Australian officials were excluded from the decisions concerning the exchange and, perhaps because of this, the White Paper was taken out of their hands. In return for the Japanese, the exchange brought back 834 Allied personnel including a total of seven Australian diplomats and twenty-three non-officials. Even the official Australian representative from

${ }^{21}$ Benda, "Beginnings of the Japanese Occupation," p. 65, footnote 8. 
Singapore and his staff were refused release! Curtin had expressed concern to London that the proposed exchange would return British personnel in preference to Australians, but to no avail.

The Archival History of this exchange stated that "lists from the Japanese Government of their nationals who should be included in the exchange were carefully checked." Doubtless, the names from Japan matched individuals in Loveday, but there was no check on their strategic value. All Japanese oil employees from the Indies were repatriated, and they were to assist the occupation forces in reaching a high production output by 1943 . All special employees from Netherlands New Guinea were repatriated, with three exceptions: a man with an injury to his right eye, another with nine children, and a sixty-year-old clerk. The occupations of the Japanese were listed as general managers, company managers, bank managers, rubber estate managers, doctors, dentists, engineers, oil technicians, etc. Some even stated that they were in the military reserve. All were repatriated, including those designated in the White Paper as "Naval spies." Nishijima was listed as a "businessman."

Kawai Tatsuo, the Japanese ambassador plenipotentiary who had arrived in Canberra in January 1941, checked the list of names from Tokyo of the Loveday internees. The ambassador had been Third Secretary in Washington in 1921 and First Secretary there since 1932. He traveled with the internees from Melbourne to Lourenco Marques, where all transferred to a Japanese ship, the Kamakura Maru, ${ }^{22}$ which had been granted safe passage to Japan. Most of the released men disembarked at Singapore. Some Japanese diplomats went to new posts in Europe direct from Lourenco Marques, by arrangement with Britain after the British ambassador in Washington, Lord Halifax, made sure this met with American approval.23

On January 27, 1943, the Director-General of Security in Canberra issued a directive: "I now lay down a standing instruction that in no instance shall an internee be released until a report has been obtained from the Camp Commandant, together with all relevant information available from Camp Intelligence and censorship reports." This directive shows that it took six months before Australian Security grasped the political ramifications of the Loveday exchange.

The history of Loveday was later published by Lt. Colonel Dean, the only internment camp commander in Australia to have compiled such a record, and this publication now reads as vindication of Dean's administration in relation to the Repatriation Exchange. In his chronology of events at Loveday, Dean commented on the Japanese who were included in the exchange. They left by rail on August 15, 1942, to board the City of Canterbury in Melbourne. "Most of those were nominated by name from Japan and it was later discovered that they were all connected with the production of rubber in Malaya and other islands." The revelation is greatly understated but it shows, nevertheless, that some information on the internees subsequently became available and was passed on to Dean.

A second exchange, proposed but never eventuated, involved Japanese deep-sea divers who had been working with Australian pearling companies. This time Allied Naval Intelligence declared that only 14 of 331 Japanese "were of little or no value to Japan." In the wake of the Loveday fiasco, this statement can be seen as overreaction. General MacArthur weighed in :

\footnotetext{
22 Kamakura was the old military capital of Japan. It survived the Mongol invasion in 1281 when the "divine wind" or kamikaze destroyed the invading fleet.

23 In 1938, when Halifax was foreign secretary, he supported a German claim to Netherlands New Guinea, a year after the Japanese Diet discussed a similar claim.
} 
I am irrevocably opposed to the return to Japan of the Japanese divers now held by the Australian government as internees. These divers would undoubtedly prove to be of the greatest value. ... The fact that the Japanese government insists so strongly on the return of these men is a clear indication of the extreme value that it places on these divers. ... No more serious or greater mistake could be made by the government of the United States than to give support to the Japanese government in the position which it holds in this affair. ${ }^{24}$

While MacArthur had evidenced no interest in the Loveday clutch of top Naval spies, he now focused zealously on deep-sea divers who were relatively harmless. His semi-recriminatory tone in addressing his superiors was possibly intended to appease the Australians' belated concern over the Loveday exchange. MacArthur was indirectly disclaiming responsibility for Loveday-the failure to utilize prior Dutch intelligence assessments of the strategic and political potential of those Japanese released. Even the American intelligence officer in Washington covering this British zone in the Southwest Pacific, Dean Rusk, has denied that he was consulted at all over the Repatriation Exchange of August 1942, and has pointed out that the State Department had ultimate responsibility. ${ }^{25}$

Of the 834 Japanese in the exchange, 703 were from the Netherlands East Indies, twentyeight had been residing in Australia, and the remainder came from New Caledonia. The timely disappearance of the Dutch intelligence report prevented ten years of security and surveillance work in the Indies being applied to the Loveday internees. Had this report been available, the convention employed in other exchanges would suggest that Japanese Naval spies and others previously engaged in underground activities in the Indies, would never have been included in the repatriation. The Allied overseers of the 1942 Loveday exchange had six months' forewarning of the contents of the White Paper, so we may surmise that all objections, particularly from the Dutch, were overruled rather than overlooked.

In January 1943 the Netherlands Embassy in Washington made another request to the State Department, obviously the recognized authority, for an exchange involving Dutch internees in the Indies and Japanese in Australia. ${ }^{26}$ In spite of the fact that the Netherlands Indies colonial government was in exile in Australia, and that the proposed exchange involved Dutch interned in the occupied Indies and Japanese interned in Australia, it was not Australia to which the proposal was directed, but Washington. Nor did the Dutch government-in-exile in London approach British authorities, which was the course of action suggested by the State Department in response to the proposed exchange. The Australian legation in Washington noted this response when notifying Canberra of the proposed exchange:

We have been informed by the British Embassy that the State Department had told them that the Netherland Embassy had approached the State Department recently with a suggestion that an exchange might be arranged via Lourenco Marques between 250 Dutch interned in Netherlands East Indies and 250 Japanese in Australia. The State Department informed the British Embassy that they replied by saying that they assumed the Dutch would take up this matter in London and that so far as they could gather the

\footnotetext{
24 Australian Archives, Brighton. MP 1049/5 Navy Correspondence Files.

25 Dean Rusk. Personal correspondence with G. Poulgrain, January 8, 1992.

26 Australian Archives, Brighton. MP 1049/5 Navy Correspondence Files. The author of this request was probably Van Mook. He had been upgraded to Lieutenant-Governor General of the Indies on January 1, 1942 (a post left vacant since 1840) and on May 25, 1942 appointed as minister of colonies. He left Australia for London and New York. Van Mook saw the hand of American anti-colonialism behind the lack of military aid prior to the war. The person responsible for apportioning US military aid was John Foster Dulles.
} 
Dutch object was to rescue a certain number of colonial administrators for training for post-war administration. 27

There was almost no likelihood of such an exchange going forward, but it is possible that, in the eyes of the Dutch, there was good reason to make the suggestion. The request showed on official records that Washington not London was the ultimate authority; it was a reflection of the first Loveday exchange, in that the proposal dealt with Japanese from Australia with the Indies as their known destination; and it showed that Dutch ambition to reclaim the Indies as a postwar colony was acknowledged by the State Department but in no way assisted. ${ }^{28}$

By the time the war ended, Nishijima and Yoshizumi were in a unique position, in the cockpit of history, having gathered together Indonesian nationalists and developed a special school for independence, ${ }^{29}$ established under the authority of Admiral Maeda of the Japanese Navy. ${ }^{30}$ Nishijima participated in the meeting in Maeda's house when the nationalists under President Sukarno drew up Indonesia's proclamation of independence. After the Japanese surrender, Yoshizumi traveled to East Java to organize guerrilla units to fight against the return of the colonial forces, first the British and then the Dutch. Nishijima, after the surrender of Japan, was arrested as a war criminal, but soon afterwards was able to return to his family in Japan.

Nishijima's political achievements weighted the scales heavily against the reestablishment of Dutch colonial administration in the Indies. His role in the historic Proklamasi, when Sukarno proclaimed Indonesian independence two days after the end of the Second World War, and his role in Indonesian-Japanese relations during the subsequent four decades, were invaluable to both Indonesia and Japan. The operational level achieved by both Yoshizumi and Nishijima, during and after the Japanese wartime occupation, merely

${ }^{27}$ Australian legation in Washington to the Department of External Affairs, Canberra, January 28, 1943. Australian Archives, Brighton, MP 1049/5 Navy Correspondence files.

${ }^{28}$ The Atlantic Charter in May 1941 was interpreted by many as laying the foundation for postwar independence for European colonies in the Far East. Yet the United States continued to assure Holland (as late as February 1944) that Dutch sovereignty would be restored in the Indies after US troops ousted the Japanese. The planned US occupation of the Indies proceeded no further than Netherlands New Guinea where geologists under MacArthur's command remained for another five years appraising its vast mineral and oil potential.

${ }^{29}$ The Navy Liaison Office which was formed in Jakarta in October 1942 gave Nishijima the opportunity to resume his prewar contacts with Indonesian nationalists. Achmad Subardjo (Indonesia's first foreign minister in 1945) was one such person. In 1943, Nishijima employed Subardjo in the Navy Office, first making military maps of New Guinea, and then translating Dutch books on New Guinea into Japanese. See: Nishijima Shigetada, "The Nationalists in Java, 1943-1945," p. 261. With the Navy Office as its political core, the Asrama Indonesia Merdeka (School for Independent Indonesia) was formed in October 1944.

${ }^{30}$ In the 1960s, after Holland relinquished sovereignty of Netherlands New Guinea, both Maeda and Nishijima were involved in negotiating oil contracts in West New Guinea. Included in the contract area was the site of a prolific oil discovery in $1972 / 3$ which flowed at $26,000 \mathrm{~b} / \mathrm{d}$. During the war when the Japanese Navy assumed control of this region, oil was being transported from this same site. See: "Intelligence Report, 1944, West New Guinea." The report, much of which was missing from its folder, was located in the file entitled "West New Guinea" in the Royal Tropical Institute, Amsterdam.

When General MacArthur took control of this region on the extreme westerly tip of New Guinea, potential oil output was estimated by US Army engineers at 25,000 b/d. See: Karl C. Dodd, Corps of Engineers: The War Against Japan-the S.W. Pacific, (Washington, DC: Office of the Chief of Military History, US Army, 1966), p. 563. Maeda, unlike Nishijima, was involved publicly in the New Guinea oil negotiations, thereby linking the 1973 bonanza (oil flowed at 170,000 b/d) with wartime intelligence and the postwar presence of American and Dutch oil interests which claimed the area was worthless. When Maeda's name was pointed out to Nishijima, his response was: "Politically, he was a naive person." Nishijima Interview. 
heightens the question of why the wartime internment of known "Naval spies" came to an end after six months.

The possibly deliberate nature of the Loveday exchange raises further questions on how the Pacific War, principally between the United States and Japan, was instrumental in replacing European colonial power in the Far East. Whoever in Washington authorized the return of Nishijima and his compatriots should also be seen as having contributed to Indonesian independence. 
